\title{
THE RÔLE OF THE UTERUS IN OVARIAN CONTROL IN THE MARE
}

\author{
G. H. STABENFELDT, J. P. HUGHES, J. D. WHEAT, J. W. EVANS, \\ P. C. KENNEDY AND P. T. CUPPS \\ Departments of Reproduction, Animal Science and Veterinary Pathology, \\ University of California, Davis, California 95616, U.S.A.
}

(Received 8th May 1973)

\begin{abstract}
Summary. The effect of hysterectomy on ovarian activity was studied in four mares. The cyclic secretion pattern of plasma progestins normally observed in the intact mare was interrupted by hysterectomy. Follicular activity was observed in all four hysterectomized mares, in spite of prolonged luteal activity, with a large number of follicles attaining ovulatory size without the occurrence of ovulation. Some ovulations were observed at irregular intervals in two out of four hysterectomized mares in spite of plasma progestin levels which ranged from 2 to $6 \mathrm{ng} / \mathrm{ml}$. While all ovulations which occurred in the hysterectomized mares were followed by the formation of CL as determined by palpation per rectum, the rise of progestins in the peripheral plasma was variable as significant increases followed CL formation in some instances but not in others. Four mares had CL with functional life spans of $48,74,75$ and 77 days at the time the experiment was terminated. There was no difference in the ability of the CL formed following these ovulations to convert pregnenolone to progesterone (per unit weight) as compared to CL of 9 days duration. The longest estimated CL life span in any hysterectomized mare was 137 days. Sexual receptivity did not occur in conjunction with follicular growth and ovulation in the hysterectomized mares in the presence of an active CL.
\end{abstract}

\section{INTRODUCTION}

No definite utero-ovarian relationship has been found in the dog (Cheval, 1934), ferret (Deansley \& Parkes, 1933), thirteen-lined ground squirrel (Drips, 1919), rhesus monkey (Burford \& Diddle, 1936; Neill, Johansson \& Knobil, 1969) and woman (Brown \& Matthew, 1962; Beling, Marcus \& Markham, 1970; Doyle, Barclay, Duncan \& Kirton, 1971). Animals in which the presence of the uterus is important for cyclic ovarian activity include the cow (Wiltbank \& Casida, 1956), sheep (Wiltbank \& Casida, 1956), pig (du Mesnil du Buisson \& Dauzier, 1959) and guinea-pig (Loeb, 1923). In the mouse (Bartke, 1970), rat (Bradbury, Brown \& Gray, 1950), hamster (Caldwell, Mazer \& Wright, 1967) and rabbit (Asdell \& Hammond, 1933), hysterectomy does not affect cyclic ovarian function but does result in prolongation of the pseudopregnant state. Recently, 
evidence has been presented that hysterectomy prolongs the life span of the CL in the non-pregnant mare (Ginther \& First, 1971). McCracken and his co-authors (1972) and Gleeson \& Thorburn (1973) have presented data that suggest prostaglandin $F_{2 \alpha}$ is an important luteolytic factor in the ewe and sow, respectively.

The current investigation, which was designed to study the rôle of the equine uterus on cyclic ovarian activity, confirms the findings of Ginther \& First (1971) and adds information concerning ovulatory control and sexual behaviour in the mare. A preliminary report has been presented previously (Stabenfeldt, Hughes, Wheat \& Evans, 1972).

\section{MATERIALS AND METHODS}

The four thoroughbred mares used in this study were hysterectomized between the 4th and 8th day after ovulation. Ovarian activity was followed daily by palpation per rectum for at least 30 days before surgery and, with the exception of a few days, for 7 to 12 months after surgery. Sexual receptivity was determined by a teaser stallion throughout the experiment, again with the exception of a few days after surgery.

Blood was collected daily from the jugular vein. Plasma progestin analysis was carried out by a competitive protein-binding assay method according to the technique of Bassett \& Hinks (1969) and as previously reported by Stabenfeldt, Hughes \& Evans (1972).

All hysterectomized mares ovulated in the spring (February to April, 1972) following a winter period of ovarian inactivity. The mares were killed 9 days after the second ovulation in the spring. Mares 32, 33, 35 and 36 had GL of 48 and 9,75 and 9,74 and 9 , and 77 and 9 days' duration, respectively, at the time of slaughter. Ovarian blood supply appeared to be normal. Examination of the anterior portion of the cervix did not reveal the presence of any uterine tissue. The structural aspects of the CL were determined histologically. The functional capability of CL was determined by measuring their ability to convert $\left[4-{ }^{14} \mathrm{C}\right]$ pregnenolone to $\left[4-{ }^{14} \mathrm{C}\right]$ progesterone (Sasser \& Cupps, 1969; Cupps, Laben \& Huff, 1970).

\section{RESULTS}

Peripheral plasma progestin levels, oestrous behaviour and ovulatory patterns in mares following hysterectomy during the luteal phase of the cycle are shown in Text-figs 1, 2 and 3. The most striking feature was the cessation of regular, cyclic progestin patterns. Following regression of CL during the winter season (the CL did not regress during the winter in one mare) and the occurrence of ovulation in the spring, progestin patterns again were acyclic. Text-figure 4 presents data from a non-pregnant, intact mare who was studied daily for approximately 1 year.

Another feature of the hysterectomized mares concerned their ovulatory pattern. Two mares, No. 35 (Text-fig. 2) and No. 36 (Text-fig. 3), did not ovulate during the prolonged luteal phase which followed hysterectomy. The 


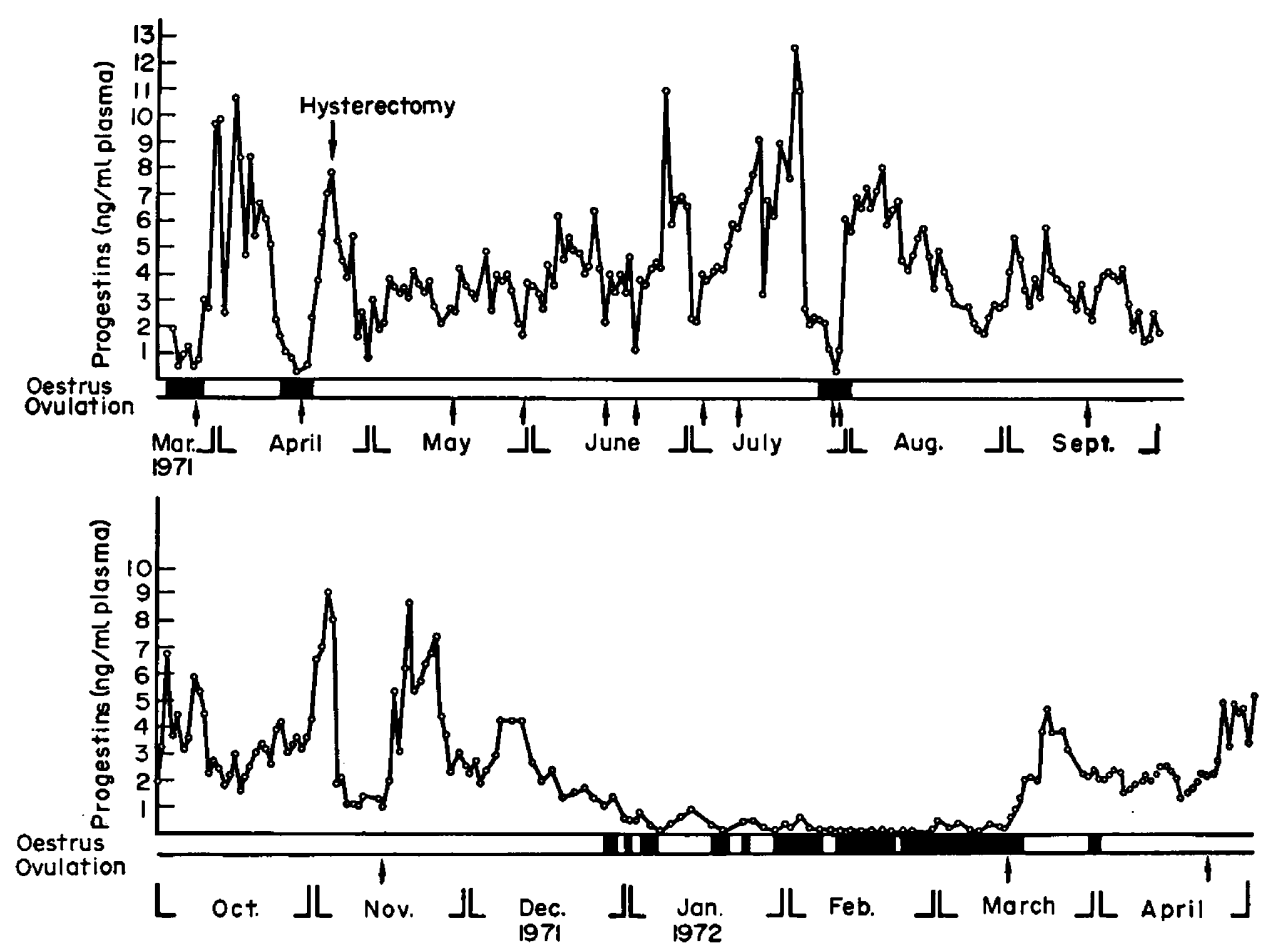

TeXT-Fig. 1. Progestin levels in the plasma of a mare (No. 32) during the oestrous cycle before hysterectomy and following hysterectomy on Day 6 after ovulation during the next cycle. Horizontal bars indicate the period of sexual receptivity. Vertical arrows indicate the occurrence of ovulation. Mare 32 was killed on 1st May 1972.

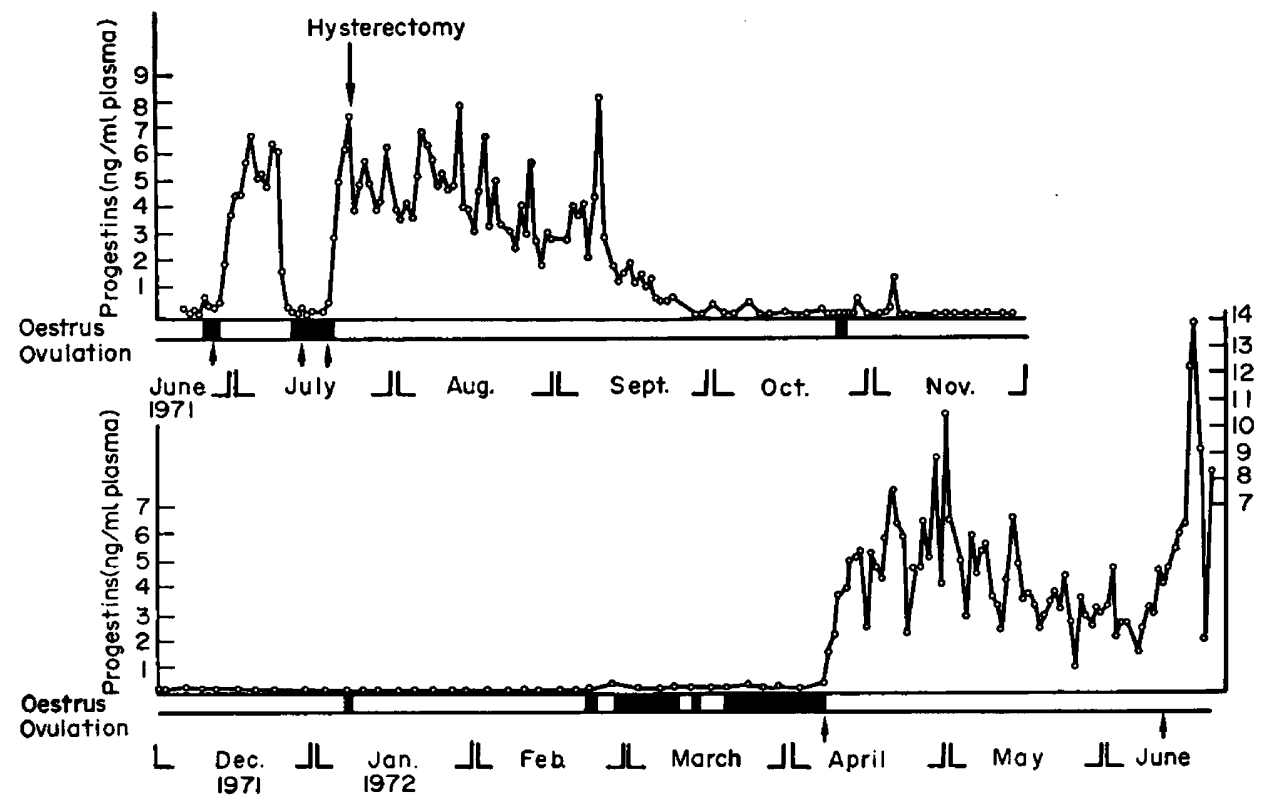

Text-Fig. 2. Progestin levels in the plasma of a mare (No. 35) during the oestrous cycle before hysterectomy and following hysterectomy on Day 4 after ovulation during the next cycle. Horizontal bars indidate the period of sexual receptivity. Vertical arrows indicate the occurrence of ovulation. Mare 35 was killed on 21st June 1972. 


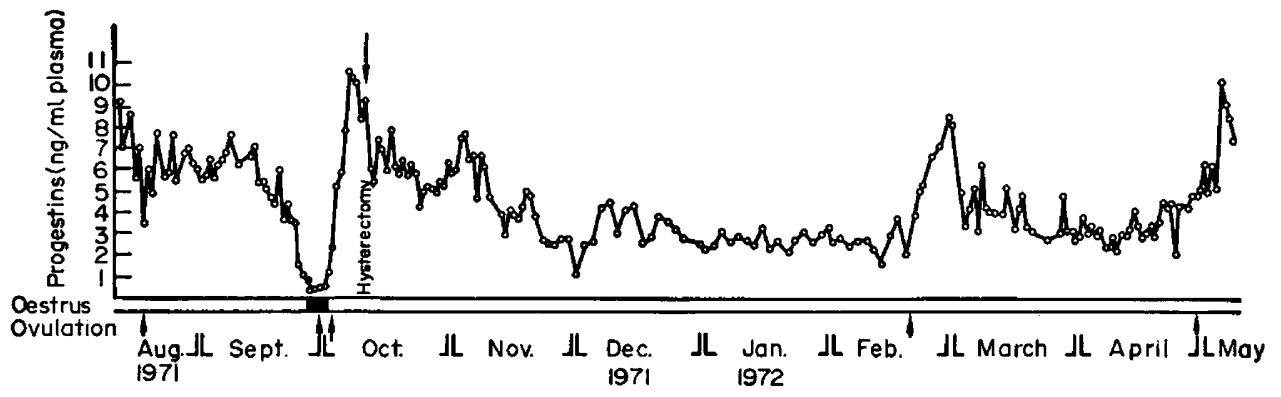

Text-Fig. 3. Progestin levels in the plasma of a mare (No. 36) before and after hysterectomy on Day 8 of the oestrous cycle. Note the spontaneously prolonged CL life span (at least 44 days) before the occurrence of oestrus in late September. Horizontal bars indicate the period of sexual receptivity. Vertical arrows indicate the occurrence of ovulation. Mare 36 was killed on 8th May 1972.
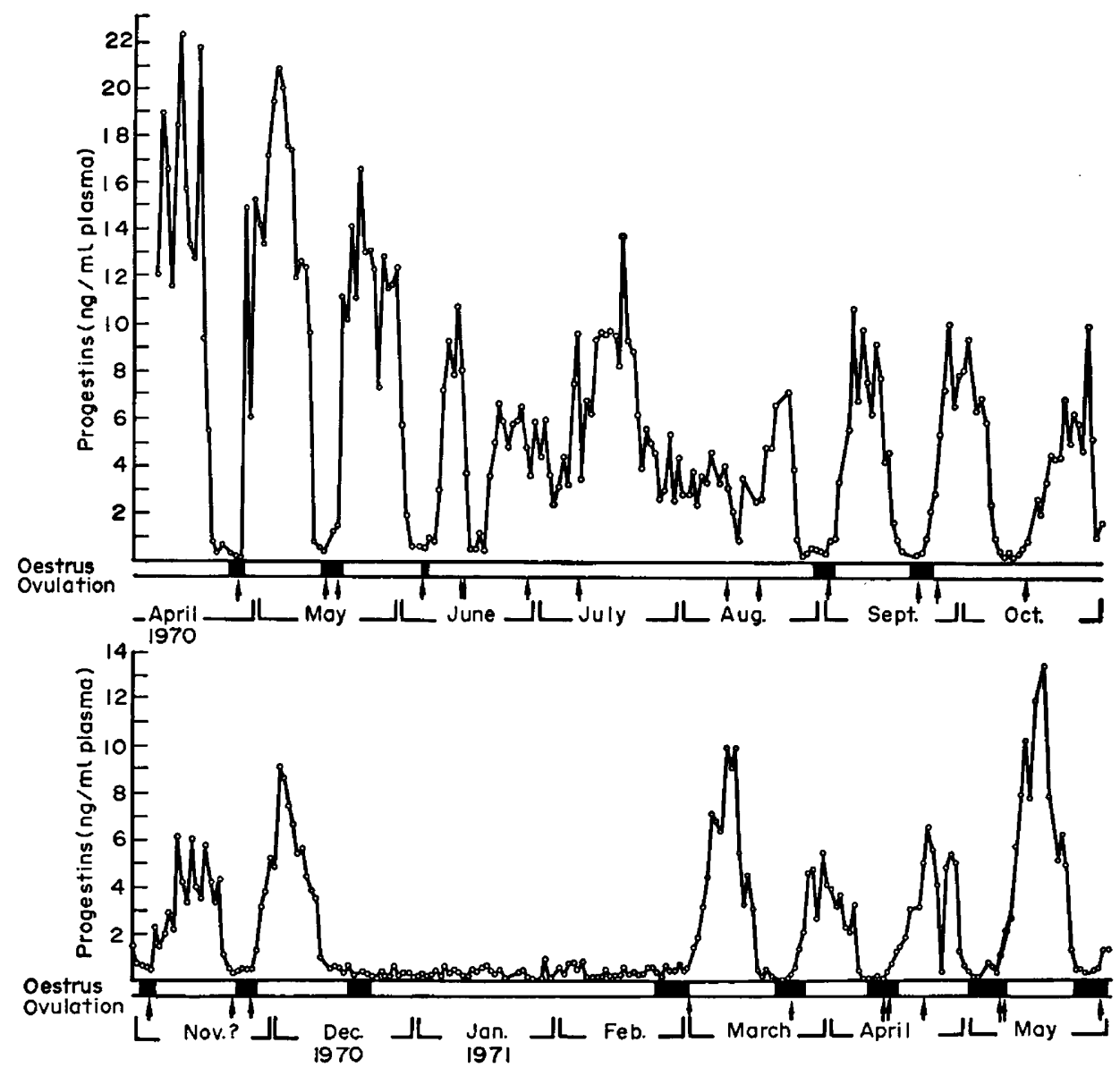

TexT-FIG. 4. Progestin levels in the blood of a non-pregnant, intact mare (No. 4) during the oestrous cycles recorded over a 15 -month period. Note the period of spontaneous prolongation of CL activity during July and August 1970 and the period of ovarian inactivity during the period from December 1970 to March 1971 . Horizontal bars indicate the period of sexual receptivity. Vertical arrows indicate the occurrence of ovulation. 
other two mares, No. 32 (Text-fig. 1) and No. 33, however, continued to ovulate in spite of the presence of active CL. The ovulations observed occurred even though progestin levels were between 2 and $6 \mathrm{ng} / \mathrm{ml}$ plasma. The presurgical ovulatory interval in mare No. 32 (Text-fig. 1) was 20 days while the post-surgical intervals ranged from 1 to 59 days. In Mare 33, the pre-surgical ovulatory interval was 21 days and, following hysterectomy, the ovulatory intervals were between 21 and 43 days. The only normal ovulatory pattern observed in any of the hysterectomized mares was observed in Mare 32 during late July and in Mares 32, 33 and 35 during the spring following a period of winter ovarian inactivity when follicular activity leading to ovulation was accompanied by sexual receptivity.

Although most of the ovulations were observed in two out of four of the hysterectomized mares, continual follicular activity was observed in all four mares. A number of follicles reached ovulatory size $(40$ to $50 \mathrm{~mm}$ ) without ovulation taking place. After a few days, these large follicles either slowly decreased in size without a change in texture or developed a firm, although somewhat gelatinous-type, consistency.

Table 1. Conversion of $\left[4-{ }^{-14} \mathrm{C}\right]$ pregnenolone to $\left[4-{ }^{14} \mathrm{C}\right]$ progesterone by corpora lutea obtained from hysterectomized mares

\begin{tabular}{|c|c|c|c|}
\hline $\begin{array}{l}\text { Mare } \\
\text { no. }\end{array}$ & $C L$ & $\begin{array}{c}\text { Age of } C L \\
\text { (days) }\end{array}$ & $\begin{array}{l}\text { Progesterone synthesized } \\
\qquad\left(\text { nmol } l^{*}\right)\end{array}$ \\
\hline $\begin{array}{c}32 \\
33 \\
35 \\
36 \\
\mathrm{X} \pm \mathrm{SD}\end{array}$ & $\begin{array}{l}\text { First } \\
\text { Second } \\
\text { First } \\
\text { Second } \\
\text { First } \\
\text { Second } \\
\text { First } \\
\text { Second }\end{array}$ & $\begin{array}{ll}48 & \\
75 & 9 \\
74 & 9 \\
77 & 9 \\
& 9\end{array}$ & 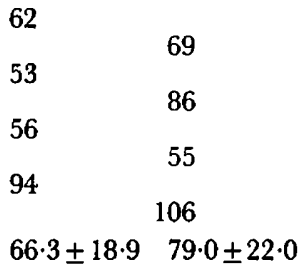 \\
\hline
\end{tabular}

* nmol $\left[4-{ }^{14} \mathrm{C}\right]$ progesterone synthesized in vitro from $\left[4-{ }^{14} \mathrm{C}\right]$ pregnenolone by $100 \mathrm{mg}$ equivalents of luteal tissue. An average of $96.6 \pm 0.7 \%$ (S.D.) of the transformed pregnenolone was recovered as progesterone.

Several of the ovulations in the hysterectomized mares were not followed by significant increases in progestin levels in the peripheral plasma, whereas other ovulations did result in significant increases in plasma progestins (Text-fig. 1). All ovulations which occurred at the end of the winter period of ovarian inactivity were followed by significant increases in progestin levels. A rise in progestins was also seen in each mare following the ovulation which occurred 9 days before autopsy.

The longest estimated life span of the $\mathrm{CL}$ in the hysterectomized mares was 137 days in Mare 36 (Text-fig. 3). At autopsy, the four hysterectomized mares had CL which ranged from 48 to 77 days in duration. The CL were found to be in the ovary predicted by palpation per rectum; three mares ovulated in the same ovary (left) whereas one mare had CL in each ovary. The older of the two CL present in each mare was lighter in colour and smaller as compared to the 
more recently formed CL (Plate 1). In addition, the prolonged CL had a distinctive white core of connective tissue which was easily seen by gross examination of the cut surface of the CL (Plate 1). Little difference, however, was observed as to the morphology of individual cells between the two sets of CL. The recently formed CL contained a loose active vascular stroma. The nuclei of capillary network cells were prominent. The cytoplasm of the luteal cells was abundant and stained a grey-rose with haematoxylin and eosin. The older CL were less vascular and the connective tissue stroma was more mature. The collagen fibres stained more deeply with eosin and the nuclei were less prominent. The cytoplasm of the luteal cells was still abundant but stained a deeper red.

The capability of the CL obtained from the hysterectomized animals to synthesize progesterone from pregnenolone in vitro is shown in Table 1. There was no significant difference between the CL which were 48, 74, 75 and 77 days of age and those which were 9 days of age. Two CL were studied 26 and 32 days after ovulation in two normal, non-pregnant mares which synthesized 0 and $21 \mathrm{nmol}$ progesterone from pregnenolone/100 mg luteal tissue, respectively.

Sexual receptivity, in general, was not observed in the mares following hysterectomy even though significant follicular activity occurred with or without ovulation. Sexual receptivity, on the other hand, was a predominant feature in the months of January, February and March (1972), particularly in Mares 32 (Text-fig. 1), 33 and 35 (Text-fig. 2). This sexual receptivity was preceded by regression of CL and occurred with only limited follicular activity present. Mare 36 (Text-fig. 3) was different in that the CL formed before surgery were apparently retained throughout the winter as progestin levels averaged about $3 \mathrm{ng} / \mathrm{ml}$ during this period. These levels were sufficient to suppress sexual receptivity.

\section{DISCUSSION}

The acyclic secretory pattern of progestins which occurred in mares following hysterectomy were interpreted as indicative of prolongation of the life span of luteal tissue. These findings are in contrast to the cyclic progestin secretory pattern observed in the non-pregnant, intact mare (see Text-fig. 4). Our hysterectomy findings are in agreement with the conclusion of Ginther \& First (1971) that the presence of the uterus is important for the periodic initiation of regression of the CL in the normal, non-pregnant mare.

All hysterectomized mares had follicular activity in spite of the continuous high levels of circulating progestins. Significant follicular activity has also been observed by us during the first few days of the luteal phase of the oestrous cycle in the non-pregnant, cyclic mare (unpublished observations) and follicular activity (and ovulation) was noted in mares in which the CL life span was spontaneously prolonged (Evans, Hughes \& Stabenfeldt, 1971). In addition, a number of investigators have presented evidence that follicle growth and ovulation do occur in the pregnant mare in spite of an active CL (Cole, Howell \& Hart, 1931; Day, 1940; Amoroso, Hancock \& Rowlands, 1948; Rowlands, 
PLATE 1

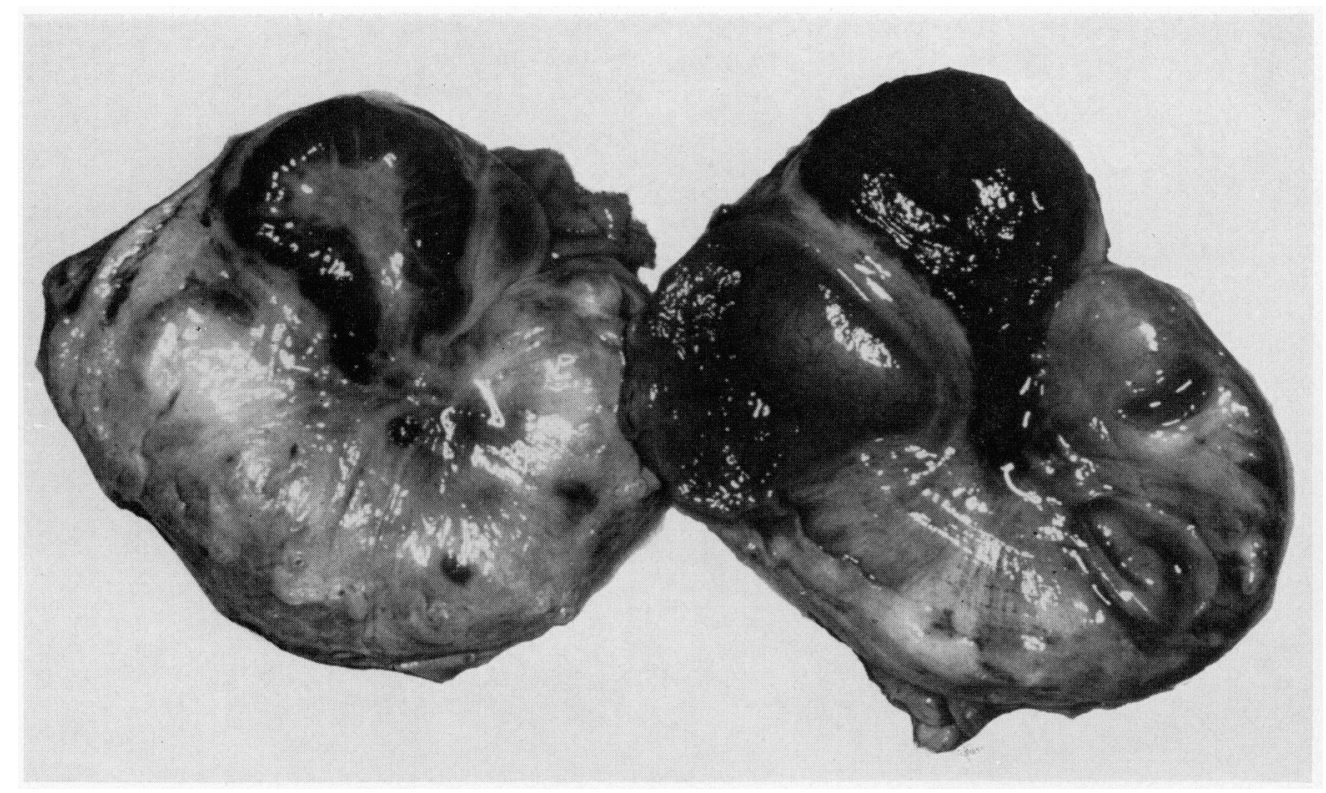

Ovaries from hysterectomized Mare 32 with a CL of 77 days duration in the left ovary (left) and 9 days duration in the right ovary (right). The inner lining of a large follicle is shown adjacent to the CL in the right ovary. Ovaries approximately three-quarters normal sizc.

(Facing p. 348) 
1949; van Rensburg \& van Heerden, 1953; van Rensburg \& van Niekerk, 1968; Allen, 1971).

Experimental support for the fact that progestins do not inhibit follicle development (and in some cases, ovulation) comes from the work of Loy \& Swan (1966). They found that the daily administration of $50 \mathrm{mg}$ progesterone beginning at mid-cycle did not suppress subsequent follicle growth and ovulation although oestrus was suppressed. Loy, Hughes, Richards \& Swan (1974) observed that three out of nine mares ovulated during the post-partum period in spite of the daily administration of $100 \mathrm{mg}$ progesterone. The failure of progesterone to suppress follicular growth in heifers and gilts has been reported although ovulation was suppressed (Ulberg, Christian \& Casida, 1951; Ulberg, Grummer \& Casida, 1951). The observations reported herein lend further support to the concept that progestins do not have a strongly suppressive effect on follicle growth, particularly in the mare. Progestins do appear to have a greater suppressive influence on ovulation as compared to follicular growth, i.e., of follicles brought to ovulatory size in the present study, the majority failed to ovulate.

The reason for the failure of progestins to rise, in some instances in the peripheral blood following ovulation in the hysterectomized animals, is not apparent. It may be that ovulation, in fact, did not occur. In all cases, however, an abrupt collapse of a $40-$ to $50-\mathrm{mm}$ follicle within a 24-hour period was followed by the formation of a structure with the resilience and texture of a CL. It is possible that ovulation was not followed by GL formation or that the newly formed CL were unable to synthesize and secrete significant amounts of progestins. These explanations are also not particularly satisfying in that we have examined at least fifteen sets of ovaries following ovulation during dioestrus in cyclic mares. All of the luteal phase ovulations were followed by the formation of normal CL as determined by gross and histological examination as well as by their ability to form progesterone from pregnenolone in an in-vitro system (unpublished observations).

It is our contention that ovarian activity in the mare, including ovulation, can be determined by palpation per rectum with a high degree of success. This has also been borne out in a subsequent series of fifteen mares (unpublished observation) in which CL were obtained at various times during the oestrous cycle with a perfect correlation between prediction of ovulatory site by rectal palpation and site of CL at autopsy.

Although follicular activity and, to a lesser extent, ovulation, were not affected by the presence of an active CL, sexual receptivity was suppressed. From our data, it appears that sexual receptivity is suppressed with progestin levels as low as 1 to $2 \mathrm{ng} / \mathrm{ml}$ plasma. Thus, the mare is very sensitive to the suppressive effects of progestins as they relate to sexual receptivity. The opposite situation, however, was observed in Mares 32 (Text-fig. 1), 33 and 35 (Text-fig. 2) during the winter following complete regression of CL. Sexual receptivity was a dominant feature during this season although follicular activity was minimal as determined by rectal palpation.

The acyclic secretory pattern of progestins observed in the hysterectomized mares is similar to those observed at times in intact mares as shown in Text-fig. 
4 and in one of the mares (No. 36, Text-fig. 3) before hysterectomy. We interpret these findings in intact mares as evidence for spontaneous prolongation of GL life span. One possible explanation, in the light of the hysterectomy study, is that the equine uterus fails at times to initiate regression of the CL. Studies of mares undergoing spontaneous prolongation of the CL could be useful in further defining the rôle of the uterus in the control of cyclic ovarian activity.

\section{AGKNOWLEDGMENTS}

The authors gratefully acknowledge the technical assistance of Miss Helen Seto, Miss Helen Burd, Mrs Margi Guzman, Mrs Mary Horton, Mr Bill Tanaka and Mr Karl Senter, as well as the aid of Dr Dean Neely and Dr Bill Stevenson. This research was supported by the California State Horseman's Association; California Experiment Station-Regional Research Project No. 1994 (W-100); the Morris Animal Foundation; and Health Sciences Advancement Award-NIH Grant RR-06138-04.

\section{REFERENGES}

ALLEN, W. E. (1971) The occurrence of ovulation during pregnancy in the mare. Vet. Rec. 88, 508.

Amoroso, E. G., Hancock, J. L. \& Rowlands, I. W. (1948) Ovarian activity in the pregnant mare. Nature, Lond. 161, 355.

Asdell, S. A. \& Hammond, J. (1933) The effects of prolonging the life of the corpus luteum in the rabbit by hysterectomy. Am. F. Physiol. 103, 600.

BARTKE, A. (1970) Influence of an IUD on the leucocytic content of the uterus and on the duration of pseudopregnancy in mice. F. Reprod. Fert. 23, 243.

Bassett, J. M. \& Hinks, N. T. (1969) Micro-determination of corticosteroids in ovine peripheral plasma: effects of venipuncture, corticotrophin, insulin and glucose. F. Endocr. 44, 387.

Beling, G. G., Marcus, S. L. \& Markham, S. M. (1970) Functional activity of the corpus luteum following hysterectomy. F. clin. Endocr. Metab. 30, 30.

Bradbury, J. T., Brown, W. E. \& Gray, L. A. (1950) Maintenance of the corpus luteum and physiologic actions of progesterone. Recent Prog. Horm. Res. 5, 151.

Brown, J. B. \& MATTHEW, G. D. (1962) IV. Steroid hormones-the application of urinary estrogen measurements to problems in gynecology. Recent Prog. Horm. Res. 18, 337.

BuRford, T. H. \& DidDLe, A. W. (1936) Effect of total hysterectomy upon the ovary of the macacus rhesus. Surg. Gynec. Obstet. 62, 701.

Caldwell, B. V., Mazer, R. S. \& Wright, P. A. (1967) Luteolysis as affected by uterine transplantation in the Syrian hamster. Endocrinology, 80, 477.

Gheval, M. (1934) Ovarian and uterine grafts. Proc. R. Soc. Med. 27, 65.

Gole, H. H., Howell, G. E. \& HART, G. H. (1931) The changes occurring in the ovary of the mare during pregnancy. Anat. Rec. 49, 199.

Gupps, P. T., LABEN, R. G. \& Hurf, R. L. (1970) Steroid metabolism in an inbred strain of Jersey cattle. 7. Dairy Sci. 53, 79.

DAY, F. T. (1940) Clinical and experimental observations on reproduction in the marc. F. agric. Sci. Camb. 30, 244.

Deanesly, R. \& Parkes, A. S. (1933) The effect of hysterectomy on the oestrous cycle of the ferret. $\mathcal{F}$. Physiol., Lond. 78, 80.

Doyle, L. L., Barclay, D. L., Duncan, G. W. \& Kirton, K. T. (1971) Human luteal function following hysterectomy as assessed by plasma progestin. Am. F. Obstet. Gynec. 110, 92.

DRIPs, D. (1919) Studies on the ovary of the spermophile (Spermophilus citellus tridecemlineatus) with special reference to the corpus luteum. Am. F. Anat. 25, 117.

du Mesnil du Buisson, F. \& Dauzier, L. (1959) Contrôle mutuel de l'utérus et de l'ovaire chez la truie. Suppl. Ann. Zootechnic (Series D), 8, 147.

Evans, J. W., Hughes, J. P. \& Stabenfeldt, G. H. (1971) The effect of season on the equine estrous cycle. 7. Anim. Sci. 33, 253.

GinTHer, O. J. \& FIRsT, N. L. (1971) Maintenance of the corpus luteum in hysterectomized mares. Am. F. vet. Res. 32, 1687. 
Gleeson, A. R. \& Thorburn, G. D. (1973) Plasma progesterone and prostaglandin F concentrations in the cyclic sow. 7. Reprod. Fert. 32, 343.

LoEB, L. (1923) The mechanism of the sexual cycle with special reference to the corpus Iuteum. Am. $\mathcal{F}$. Anat. 32, 305.

Loy, R. G., Hughes, J. P., Richards, W. P. C. \& Swan, S. M. (1974) Effects of progesterone on reproductive function in postpartum mares. Am. F. vet. Res. (in press).

Loy, R. G. \& SWAN, S. M. (1966) Effects of exogenous progestogens on reproductive phenomena in mares. F. Anim. Sci. 25, 821 .

McGracken, J. A., Garlson, J. G., Glew, M. E., Goding, J. R., Baird, D. T., Green, K. \& Samuelsson, B. (1972) Prostaglandin $F_{2 \alpha}$ identified as a luteolytic hormone in sheep. Nature, New Biol. 238, 129.

Neill, J. D., Johansson, E. D. B. \& Knobil, E. (1969) Failure of hysterectomy to influence the normal pattern of cyclic progesterone secretion in the rhesus monkey. Endocrinology, 84, 464.

RoWLANDS, I. W. (1949) Serum gonadotrophin and ovarian activity in the pregnant mare. F. Endocr. 6, 184.

SAsser, R. G. \& GuPPs, P. T. (1969) Conversion of pregnenolone- $4{ }^{14} \mathrm{C}$ to progesterone- $-4^{14} \mathrm{C}$ by bovine luteal tissue at selected stages of the estrous cycle. F. Dairy Sci. 52, 217.

Stabenfeldt, G. H., Hughes, J. P. \& Evans, J. W. (1972) Ovarian activity during the estrous cycle of the mare. Endocrinology, 90, 1379.

Stabenfeldt, G. H., Hughes, J. P., Wheat, J. D. \& Evans, J. W. (1972) The role of the uterus of the mare in cyclic ovarian activity. Fedn Proc. Fedn Am. Socs exp. Biol. 31, 265.

Ulberg, L. G., Ghristian, R. E. \& Casida, L. E. (1951) Ovarian response in heifers to progesterone injections. F. Anim. Sci. 10, 752.

Ulberg, L. G., Grummer, R. H. \& Gasida, L. E. (1951) The effects of progesterone upon ovarian function in gilts. F. Anim. Sci. 10, 665 .

van Rensberg, S. W. J. \& van HEERden, J. S. (1953) Infertility in mares caused by ovarian dysfunction. Onderstepoort F. vet. Res. 26, 285.

van Rensberg, S. W. J. \& VAN NIEkerk, G. H. (1968) Ovarian function, follicular oestradiol-17 $\beta$, and luteal progesterone and $20 \alpha$-hydroxy-pregn-4-en-3-one in cycling and pregnant equines. Onderstepoort 7. vet. Res. 35, 301.

Wiltbank, J. N. \& Gasida, L. E. (1956) Alteration of ovarian activity by hysterectomy. F. Anim. Sci. 15, 134. 